\title{
DECISION-MAKING DURING LIMITED NUMBER OF EXPERIMENTS WITH MULTIPLE CRITERIA
}

Irodov V. F. - Dr. Sc., Professor, Head of the Department of system analysis and modelling in heat and gas supply, Prydniprovska State Academy of Civil Engineering and Architecture, Dnieper, Ukraine.

Barsuk R. V. - Assistant of the Department of system analysis and modelling in heat and gas supply, Prydniprovska State Academy of Civil Engineering and Architecture, Dnieper, Ukraine.

\begin{abstract}
Context. The mechanism of decision-making during limited number of experiments with multiple criteria are considered. The investigation object is process decision-making for project or control in complex systems with multiple criteria.

Objective. It is necessary to determine optimal (most preferred) parameters of the systems with multiple criteria. It is no the mathematical model of the system, there is limited number of experiments only.

Method. A scheme is proposed for constructing a selection mechanism for decision-making in systems with several criteria for which there is a sample of experimental results. The scheme includes the following procedures: an experimental study of a process with several criteria (functions) depending on its parameters; the use of expert evaluation to build a matrix of preferences for individual implementations; building a function of choosing preferred solutions based on a preference matrix by constructing a mathematical model of preference recognition, formulation and solving the problem of generalized mathematical programming as the final step in building the selection mechanism. The decision-making mechanism depends on the expert assessment procedure when comparing a limited set of results with each other, as well as on the statement of conditions when solving the problem of generalized mathematical programming. Comparison of a finite number of experiments is convenient for expert evaluation. Presentation of the final choice as a result of solving the problem of generalized mathematical programming is convenient for using such a mechanism in automatic control systems already without human intervention.

Results. The proposed scheme of decision-making during limited number of experiments has been applied to decision-making of project management for pellet burner. Experimental decision-making results are presented in the presence of several criteria for a pellet burner of a tubular heater, which confirm the acceptability of the developed decision-making mechanism.

Conclusions. It was proposed the new scheme for constructing a selection mechanism for decision-making in systems with several criteria where there is a sample of experimental results only. The scheme of decision-making is includes the solving the problem of generalized mathematical programming as the final step in building the selection mechanism. For the solving the problem of generalized mathematical programming may be applied the evolution search algorithm.
\end{abstract}

KEYWORDS: decision-making, multiple criteria, function of choosing, generalized mathematical programming.

\section{NOMENCLATURE}

$A$ is an ash transfer in time;

$a_{1}, a_{2}, \ldots, a_{18}$ are choice function parameters;

$x$ is a set of inlet system parameters;

$x^{i}$ is a scalar parameters (continuous or discrete);

$\Omega$ is the set of admissible parameters;

$x_{0}$ is $R_{S}$ - optimal solution at the set $\Omega$;

$x_{H}$ is a new solution;

$z$ is a set of outlet system functions (parameters);

$z^{f}$ is a one from output parameters

$R_{S}$ is a binary choice relation;

$R_{G}$ is a fuzzy generation relation;

$S(X)$ is a selection function;

$G(X)$ is a generation function;

$G_{H}(X)$ is a set of new solutions;

$B_{o b}$ is the table of experimental results;

$B$ is a matching matrix of experimental results;

$C$ is an incomplete choice function;

$\Gamma(x)$ is the choice function;

$\pi$ is the choice rule;

$R_{S}^{+}(x)$ is the upper section to the binary choice relation $R_{S}$;

$N_{o b}$ is a number of experiments;

$N_{b}$ is a number of branches for evolutionary search;

$N_{E}$ is a number of new solutions (hevristics);
$N_{o p}$ is a number of preferred solutions;

$S_{b}$ is a burner area;

$S_{f i r}$ is a useful area for primary air;

$L_{1}$ is a primary air flow;

$L_{\text {tot }}$ is a total air flow;

$X$ is a subset of parameters;

$X_{k}$ is a set of preferred solutions according to the binary choice relation $R_{S}$ at the iterate step $k$;

$k$ is an iterate step;

$X_{k-1}$ is a set of preferred solutions according to the binary choice relation $R_{S}$ at the iterate step $k-1$;

$X_{j k}$ is a set of preferred solutions according to the binary choice relation $R_{S}$ at the iterate step $k$ for the branch $j$ of evolutionary search;

$W$ is a power of burner.

\section{INTRODUCTION}

The basis of the research is an experiment in which the permissible range of parameters determining the state of the system is comprehensively investigated. In each experiment, in addition to the input parameters of the system, the output functions (criteria) of the system under study are measured or calculated. If we confine ourselves only to the experimental sampling of parameters, then it will not be possible to make decisions about the preference of the system parameters over the entire allowable area. It is advisable to build a mathematical model of the 
function of choice, which will allow to extend the rule of preferences of parameters to the entire admissible region. Having an expression for the function of choice, we can formulate and solve the problem of finding the most preferable solutions. The search of the most preferable solutions can be implemented as a result of solving a generalized mathematical programming problem

The object of study is the process of decision-making while developing or managing systems with some parameters. The mathematical model of such a system is used to make decisions for the development or management of systems. The mathematical model of the system can be built on the basis of deductive laws of functioning or on the basis of an experimental study of the system.

The subject of study is the process of decisionmaking for project or control in complex systems with multiple criteria when information about the system is presented in the form of a limited set of experiment results.

The purpose of the work is to increase the speed the decision-making process for a system with several criteria when setting information about the properties of the system is a set of experimental results.

\section{PROBLEM STATEMENT}

A system is characterized by a set of parameters $x=$ $\left\{x^{1}, x^{2}, \ldots, x^{n}\right\}, x \in \Omega$ and a set of output parameters (functions, criteria) $z=\left\{z^{1}, z^{2}, \ldots, z^{f}\right\}$. There are training set of experimental results: $B_{o b}=\left\langle x_{q} y_{q}>, q=1,2, \ldots, N_{o b}\right.$ and the result of the expert evaluation in the form of the matching matrix $B=\left\{b_{i j}\right\}, i=1,2, \ldots, N_{o b}, j=1,2, \ldots, N_{o b}$, which is obtained using expert choice relation $R$.

It is required to find the choice function $C$ for all set $\Omega$ with binary relation $R_{S}$ such that binary relation $R_{S}$ corresponds with expert choice relation $R$.

\section{REVIEW OF THE LITERATURE}

In the study of certain processes and systems, the goal is often set - to find the "best" values of the parameters of the system under study. Here we will consider such properties of the system that are not formulated using the deductive approach. Then the basis for the study can only be an experiment. As a result of the experiment, an experimental sample of the values of the system parameters and the corresponding values of the functions (criteria) characterizing these states will be obtained.

The traditional approach is to build mathematical models for each function (criterion) separately based on a sample of experimental data. The search for the "best" parameters of the system can be carried out using a set of mathematical models for the criteria. But how to compare several criteria with each other with the traditional approach remains open.

An alternative approach, which is described here, is as follows. The basis of the research is an experiment in which the permissible range of parameters determining the state of the system is comprehensively investigated. In each experiment, in addition to the input parameters of the system, the output functions (criteria) of the system under study are measured or calculated. If we confine ourselves only to the experimental sampling of parameters, then it will not be possible to make decisions about the preference of the system parameters over the entire allowable area.

It is advisable to build a mathematical model of the function of choice, which will allow "to extend" the rule of preferences of parameters to the entire admissible region. Having an expression for the function of choice, we can formulate and solve the problem of finding the most preferable solutions.

To date, there is sufficient experience in using binary relations of choice in constructing a mechanism for choosing decisions, in particular, scientific results [1-4] and other.

If there is a system that does not have a reliable mathematical model based on deductive laws of functioning, then the inductive principles of mathematical modelling of such systems are known $[5,6]$ that have received significant development. In inductive modelling, various mathematical models were constructed from experimental data. In this case, it is possible to build functional dependencies for each of several output functions of the system. Having mathematical dependencies for several output functions, you can solve the decision problem as a multiobjective optimization problem. There is a fairly large number of scientific results in the field of multi-optimized optimization [7-10].

Most of these results relate to the situation where there are mathematical models for each of the output functions - Pareto optimization. In this case, the adoption of the final decision from the set of Pareto-optimal is an additional procedure.

An alternative approach is the formulation of an optimization problem as an optimization task with respect to choice relation. Previously, generalized mathematical programming problems were formulated for which solution methods were proposed $[11,12]$ and other. Later works are also devoted to solving the problem of generalized mathematical programming, for example [13]

Effective methods for solving optimization problems are developed on the basis of evolutionary search algorithms, for example, [14-16]. Including evolutionary algorithms useful for solving problems of generalized mathematical programming $[16,17]$ without the convexity condition of choice relation.

Previously, it was not offered a general scheme for constructing a selection mechanism for decision-making in systems with several criteria where there is a sample of experimental results only. The scheme of decisionmaking is includes the solving the problem of generalized mathematical programming as the final step in building the selection mechanism. For the solving the problem of generalized mathematical programming may be applied the evolution search algorithm.

\section{MATERIALS AND METHODS}

Let a system be considered whose state is characterized by a set of parameters $x=\left\{x^{1}, x^{2}, \ldots, x^{n}\right\}$. Each system 
state is characterized by a set of output parameters (functions, criteria) $z=\left\{z^{1}, z^{2}, \ldots, z^{f}\right\}$.

We assume that as a result of the experiments, a training set of experimental results was obtained: $B_{o b}=<x_{q} y_{q}>, q=1,2, \ldots, N_{o b}$. In terminology of the theory of decision making [2-4], a separate result of the sample will be called presentation. We assume that the set of presentations of the training sample $B_{o b}$ by expert evaluation taking into account the values of output functions for any pair of presentations, a binary relation $R_{S}: x_{i}$ $R_{S} x_{j}$ for $i, j=1,2, \ldots, N_{o b}$ is established. The result of the expert evaluation for the comparison of the presentations with each other will be represented in the form of the matching matrix $B=\left\{b_{i j}\right\}, i=1,2, \ldots, N_{o b}, j=1,2, \ldots, N_{o b}$, where

$$
\begin{cases}b_{i j}=1, & \text { if } \quad x_{i} R x_{j} \\ b_{i j}=0, & \text { if } \quad x_{j} R x_{i}\end{cases}
$$

We will search for the selection rule $\pi$ with the selection function

$$
S(X)=\left\{x \in X \mid \forall y \in[X \backslash S(X)], x R_{S} y\right\} .
$$

and the binary relation $R_{S}$, which is determined by the function $\Gamma(x)=\Gamma\left(x^{1}, x^{2}, \ldots, x^{n}\right)$, such that

where $x_{1} \in \Omega, x_{2} \in \Omega$

$$
\Gamma\left(x_{1}\right) \geq \Gamma\left(x_{2}\right) \equiv x_{1} R_{S} x_{2} .
$$

The function $\Gamma(x)$ is defined on the whole set of admissible parameters $\Omega$ and the binary relation $R_{S}$ is defined for all pairs of elements from $\Omega$, and not just for pairs of elements from the set of experimental results.

In this sense, we can talk about the problem of approximation [4]. The function $\Gamma(x)$ and the binary relation $R_{S}$ should be determined from the condition of the best fit to the matrix $B=\left\{b_{i j}\right\}, i=1,2, \ldots, N_{o}, j=1,2, \ldots, N_{\mathrm{o}}$ for comparison of objects according to the results of experiments.

The binary relation $R_{S}$ with the choice function obtained in this way can be used to search for the most preferable solutions on the entire $\Omega$ set, taking into account possible limitations as well.

Following the terminology of [2], the choice rule is a rule, according to which there can be an by element or integral definition of the choice function:

$$
\begin{gathered}
\pi: y \in X \mid \ldots \\
\pi: \mathrm{Y} \subseteq X \mid \ldots
\end{gathered}
$$

In these formulas, instead of the ellipsis, one or another record of the corresponding conditions, which characterize the choice rule, is meant.

The task of the synthesis [2] is to construct a mechanism of choice that implements this function based on the function of the (incomplete) choice $C$, or to establish that it cannot be done. The function $C$, for which the synthesis problem is solved, can describe the experimentally observed choice.

The article aims to offer a rational scheme for making the most preferable solutions for researching a system with several criteria, ranging from experimental research of the system and obtaining a sample of experimental data, ending with the formulation and solution of the problem of finding the most preferred parameters as a generalized mathematical programming problem.

To achieve this goal, it was necessary to develop a method for constructing a function of choice, based on a sample of experiments, and then to extend the function of choice to the whole admissible region. In addition, it was necessary to develop or choose from previously developed such a method for solving the problem of generalized mathematical programming, which will allow to provide a final search for the most preferable solution on the permissible parameter area in the presence of constraints.

The methods for solving the problems are based on the approach to the evolutionary search for $R_{S}$ - optimal solutions. For subset $X, X \subset \Omega$ we denote the function of choice in the form

$$
S(X)=\left\{x \in X \mid \forall y \in[X \backslash S(X)], x R_{S} y\right\} .
$$

We shall assume that set $S(X)$ contains the concrete number of elements $-N_{o p}$.

We shall that for the set $\Omega$ it was determined relation $R_{G}$ with attachment function $\mu_{R_{G}}(x, y): \Omega \times \Omega \rightarrow[0,1]$. Relation $R_{G}$ will be termed generation relation.

For subset $X, X \subset \Omega$ we denote the function of generation in the form

$$
\begin{gathered}
G(X)=X \cup G_{H}(X), \\
G_{H}(X)=\left\{y \in \Omega \mid \exists x \in X, y R_{G} x, \mu_{R_{G}}(x, y)>0\right\} .
\end{gathered}
$$

We shall assume that set $G(X)$ contains the concrete number of elements $-N_{E}$.

The algorithm to search $R_{S}$-optimal solution can be represented as

$$
X_{k}=S\left(G\left(X_{k-1}\right)\right), k=1,2, \ldots
$$

The iterate algorithm (3) - is the general form of evolutionary search.

According to [15-17] we will consider the decomposition

$$
X_{k}=\bigcup_{j=1}^{N_{b}} X_{j k}, X_{i k} \cap X_{j k}=\varnothing, i \neq j .
$$

The algorithm (3) takes the form

$$
X_{j k}=S\left(G\left(X_{j k-1}\right)\right), j=\overline{1, N_{b}}, k=1,2, \ldots
$$

These iterate algorithms (3), (5) - are the general form of evolutionary search.

We denote by $R_{S}^{+}(x)$ the upper section to the binary choice relation $R_{S}$ at the set $\Omega$ :

$$
R_{S}^{+}(x)=\left\{y \in \Omega \mid y R_{S} x\right\} .
$$

We will assume that upper sections have such properties:

$$
\forall x \neq x_{0} \quad \operatorname{mes}_{S}^{+}(x)>0 .
$$

Relatively of generation function we will consider following. If $x_{H}$ is a new solution $x_{H} \in G_{H}(X)$, then

$$
\forall x \neq x_{0} \quad P\left\{x_{H} \in R_{S}^{+}(x)\right\} \geq \delta>0 \text {. }
$$


Convergence of the sequence $X_{k}$ to $R_{S}$-optimal solution we understand the following. For every $x \in \Omega$, $x \neq x_{0}$ there is a number $K$ that for each $k \geq K$ with probability 1 that will be satisfied:

$$
X_{K} \subset R_{S}^{+}(x) \text {. }
$$

The following theorem [13] holds:

If upper sections (6) have the property (7), generation function (2) has the property (8), and choice relation $R_{S}$ is a no strictly order relation, then algorithm (3) ensures convergence of the sequence $X_{k}$ to $R_{S}$ - optimal solution with probability 1 .

Analogically [16] this theorem can be extended for all branches of evolutionary search (5).

\section{EXPERIMENTS}

There are considered tubular gas heater [18]. Tubular heaters design parameters (inlet system parameters) are below:

- Burner area, $S_{b}$;

- Useful area for primary air passage, $S_{f i r}$;

- Primary air flow, $L_{l}$;

- Total air flow, $L_{t o t}$;

- Burner power, $W$.

There are criteria (outlet system functions) of the heater:

- Ash transfer by the time, $A$;

- Concentration $C O$ at exhaust gases, $C_{C O}$;

- Concentration $N O_{x}$ at exhaust gases, $C_{N O x}$.

There are following requirements for parameters that characterize tubular heaters work: for $C O$ it is less than $130 \mathrm{mg} / \mathrm{m}^{3}$ and for $N O_{x}-$ less than $250 \mathrm{mg} / \mathrm{m}^{3}$. Therefore such tags as $C O$ and $N O_{x}$ are shown at tubular heater schematically block diagram. Also such parameter as ash is typical because of strengthened primary air supply creates unintended carrying out ash from the burner. It leads to tube clogging, which degrades heat transfer and reduces tube efficiency time.

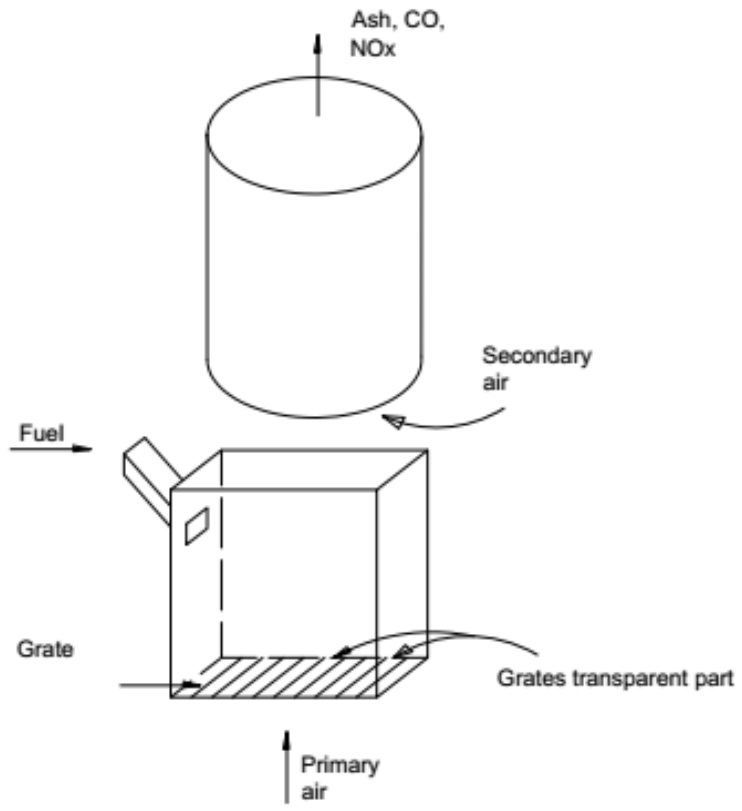

Figure 1 - Tubular heater pellets burner principle diagram

Experimental results are presented in two arrays: array 1 (Table 1) and array 2 (Table 2).

After expert evaluation of array 1 (Table 1) and array 2 (Table 2), matching matrixes B were obtained - Table 3 and Table 4.

Table 1 - Experimental data array 1

\begin{tabular}{|c|c|c|c|c|c|c|c|c|}
\hline & & & & & & & $\max =130$ & $\max =250$ \\
\hline № & S & $\mathrm{S}$ пер & $\mathrm{L}_{\text {заг }}$ & $\mathrm{L}_{1}$ & $\mathrm{~W}$ & 3 & $\mathrm{C}_{\mathrm{CO}}$ & $\mathrm{C}_{\mathrm{NOx}}$ \\
\hline 1 & 0.5 & 0.572 & 0.7155 & 0.440252 & 0.335 & 0.175 & 0.012 & 0.964 \\
\hline 2 & 0.5 & 0.572 & 0.6795 & 0.430464 & 0.313 & 0.240 & 0.153 & 0.681 \\
\hline 3 & 0.5 & 0.572 & 0.6795 & 0.397 & 0.547 & 0.231 & 0.001 & 0.852 \\
\hline 4 & 1 & 0.643 & 0.792 & 0.738 & 0.18 & 0.018 & 0.102 & 0.845 \\
\hline 5 & 1 & 0.643 & 0.8145 & 0.828 & 0.32 & 0.039 & 0.016 & 0.674 \\
\hline 6 & 1 & 0.643 & 0.855 & 0.736 & 0.355 & 0.458 & 0.003 & 0.757 \\
\hline 7 & 1 & 0.643 & 0.7785 & 0.924 & 0.828 & 0.233 & - & - \\
\hline 8 & 0.5 & 0.254 & 0.8865 & 0.38 & 0.26 & 0.024 & - & - \\
\hline 9 & 0.5 & 0.245 & 0.7425 & 0.484 & 0.32 & 0.018 & - & - \\
\hline 10 & 0.5 & 0.254 & 0.7515 & 0.509 & 0.36 & 0.010 & - & - \\
\hline 11 & 1 & 0.287 & 0.819 & 0.769 & 0.3 & 0.083 & - & - \\
\hline 12 & 1 & 0.287 & 0.774 & 0.872 & 0.6 & 0.278 & - & - \\
\hline 13 & 1 & 0.287 & 0.742 & 0.787 & 0.94 & 0.202 & - & - \\
\hline 14 & 0.5 & 0.572 & 0.723 & 0.218 & 0.18 & - & 0.051 & 0.431 \\
\hline 15 & 0.5 & 0.572 & 0.671 & 0.134 & 0.2 & - & 0.016 & 0.753 \\
\hline 16 & 0.25 & 0.084 & 0.25125 & 0.134 & 0.064 & 0.298 & 0.063 & 0.293 \\
\hline 17 & 0.25 & 0.084 & 0.21 & 0.244 & 0.09 & 0.583 & 0.066 & 0.441 \\
\hline 18 & 0.25 & 0.084 & 0.20625 & 0.26 & 0.18 & 0.833 & 0.164 & 0.359 \\
\hline 19 & 0.25 & 0.084 & 0.188 & 0.337 & 0.18 & 0.583 & 0.178 & 0.411 \\
\hline 20 & 0.25 & 0.084 & 0.268 & 0.102 & 0.047 & 0.133 & 0.032 & 0.48 \\
\hline 21 & 0.25 & 0.084 & 0.25125 & 0.139 & 0.113 & 0.408 & 0.03 & 0.635 \\
\hline 22 & 0.25 & 0.084 & 0.245 & 0.153 & 0.1 & 0.417 & 0.023 & 0.691 \\
\hline 23 & 0.25 & 0.084 & 0.2275 & 0.214 & 0.128 & 0.300 & 0.018 & 0.697 \\
\hline 24 & 0.25 & 0.084 & 0.2225 & 0.14 & 0.053 & 0.150 & 0.018 & 0.661 \\
\hline 25 & 0.25 & 0.084 & 0.208 & 0.167 & 0.045 & 0.058 & 0.049 & 0.526 \\
\hline
\end{tabular}

(C) Irodov V. F., Barsuk R. V., 2020

DOI 10.15588/1607-3274-2020-1-20 
e-ISSN 1607-3274 Радіоелектроніка, інформатика, управління. 2020. № 1

p-ISSN 2313-688X Radio Electronics, Computer Science, Control. 2020. № 1

Table 2 - Experimental data array 2

\begin{tabular}{|c|c|c|c|c|c|c|c|c|}
\hline & & & & & & & $\max =130$ & $\max =250$ \\
\hline № (cont.) & $\mathrm{S}$ & $\mathrm{S}$ пер & $\mathrm{L}_{\text {заг }}$ & $\mathrm{L}_{1}$ & W & 3 & $\mathrm{C}_{\mathrm{CO}}$ & $\mathrm{C}_{\mathrm{NOx}}$ \\
\hline 26 & 0.25 & 0.084 & 0.194 & 0.194 & 0.06 & 0.142 & 0.016 & 0.872 \\
\hline 27 & 0.25 & 0.084 & 0.187 & 0.233 & 0.112 & 0.233 & 0.014 & 0.852 \\
\hline 28 & 0.25 & 0.084 & 0.175 & 0.285 & 0.18 & 0.450 & 0.026 & 0.789 \\
\hline 29 & 0.25 & 0.084 & 0.17 & 0.33 & 0.225 & 0.875 & 0.019 & 0.845 \\
\hline 30 & 0.25 & 0.084 & 0.16 & 0.546 & 0.225 & 0.942 & 0.018 & 0.859 \\
\hline 31 & 0.25 & 0.084 & 0.158 & 0.197 & 0.082 & 0.158 & 0.025 & 0.441 \\
\hline 32 & 0.25 & 0.084 & 0.15375 & 0.2439 & 0.09 & 0.083 & 0.010 & 0.618 \\
\hline 33 & 0.25 & 0.084 & 0.13875 & 0.306 & 0.113 & 0.158 & 0.006 & 0.497 \\
\hline 34 & 0.25 & 0.084 & 0.131 & 0.362 & 0.15 & 0.250 & 0.01 & 0.625 \\
\hline 35 & 0.25 & 0.084 & 0.121 & 0.422 & 0.15 & 0.400 & 0.028 & 0.783 \\
\hline 36 & 0.25 & 0.084 & 0.106 & 0.588 & 0.225 & 0.858 & 0.019 & 0.668 \\
\hline 37 & 0.25 & 0.084 & 0.1 & 0.8125 & 0.18 & 0.900 & 0.021 & 0.714 \\
\hline 38 & 0.25 & 0.084 & 0.2625 & 0.13 & 0.039 & 0.108 & 0.067 & 0.53 \\
\hline 39 & 0.25 & 0.084 & 0.21875 & 0.234 & 0.09 & 0.283 & 0.151 & 0.184 \\
\hline 40 & 0.25 & 0.084 & 0.215 & 0.25 & 0.075 & 0.467 & 0.065 & 0.487 \\
\hline 41 & 0.25 & 0.084 & 0.21 & 0.303 & 0.18 & 0.292 & 0.045 & 0.431 \\
\hline 42 & 0.25 & 0.084 & 0.19 & 0.145 & 0.05 & 0.417 & 0.042 & 0.382 \\
\hline 43 & 0.25 & 0.084 & 0.186 & 0.188 & 0.075 & 0.333 & 1 & 1 \\
\hline 44 & 0.25 & 0.084 & 0.18875 & 0.198 & 0.113 & 0.317 & 0.09 & 0.26 \\
\hline
\end{tabular}

Table 3 - Matching matrix for experimental data array 1

DATA $1,1,1,1,1,1,1,1,1,1,1,1,1,1,1,1,0,0,0,1,1,1,1,1,1$

DATA $0,1,1,0,1,1,1,1,1,1,1,1,1,1,1,1,1,0,0,1,1,1,1,1,1$

DATA $0,0,1,0,0,1,1,1,1,1,1,0,1,0,0,0,0,0,0,0,0,0,0,0,0$

DATA $0,1,1,1,0,1,0,1,1,1,0,0,0,0,0,0,0,0,0,0,0,0,0,0,0$

DATA $0,0,1,1,1,1,0,1,1,1,0,0,0,0,0,0,0,0,0,0,0,0,0,0,0$

DATA $0,0,0,0,0,1,1,1,1,1,1,1,1,0,0,0,0,0,0,0,0,0,0,0,0$

DATA $0,0,0,1,1,0,1,1,1,1,0,0,1,0,0,0,0,0,0,0,0,0,0,0,1$

DATA $0,0,0,0,0,0,0,1,1,1,0,0,0,0,0,0,0,0,0,0,0,0,0,0,0$

DATA $0,0,0,0,0,0,0,0,1,1,0,0,0,0,0,0,0,0,0,0,0,0,0,0,0$

DATA $0,0,0,0,0,0,0,0,0,1,0,0,0,0,0,0,0,0,0,0,0,0,0,0,0$

DATA $0,0,0,1,1,0,1,1,1,1,1,0,1,0,1,0,0,0,0,0,0,0,0,0,0$

DATA $0,0,1,1,1,0,1,1,1,1,1,1,1,0,1,0,0,0,0,0,0,0,0,0,0$

DATA $0,0,0,1,1,0,0,1,1,1,0,0,1,0,1,0,0,0,0,0,0,0,0,0,0$

DATA $0,0,1,0,1,1,1,1,1,1,1,1,1,1,1,0,0,0,0,1,1,1,1,1,1$

DATA $0,0,1,0,1,1,1,1,1,1,0,0,0,0,1,0,0,0,0,0,0,0,0,0,0$

DATA $0,0,1,0,1,1,1,1,1,1,1,1,1,1,1,0,0,0,1,1,1,1,1$,

DATA $1,0,1,0,1,1,1,1,1,1,1,1,1,1,1,1,1,0,0,1,1,1,1,1,1$

DATA $1,1,1,0,1,1,1,1,1,1,1,1,1,1,1,1,1,1,0,1,1,1,1,1,1$

DATA $1,1,1,0,1,1,1,1,1,1,1,1,1,1,1,1,1,1,1,1,1,1,1,1,1$

DATA $0,0,1,0,1,1,1,1,1,1,1,1,1,0,1,0,0,0,0,1,0,1,1,1,0$

DATA $0,0,1,0,1,1,1,1,1,1,1,1,1,0,1,0,0,0,0,1,1,1,1,1,0$

DATA $0,0,1,0,1,1,1,1,1,1,1,1,1,0,1,0,0,0,0,0,0,1,1,1,0$

DATA $0,0,1,0,1,1,1,1,1,1,1,1,1,0,1,0,0,0,0,0,0,0,1,0,1$

DATA $0,0,1,0,1,1,1,1,1,1,1,1,1,0,1,0,0,0,0,0,0,0,1,1,0$

DATA $0,0,1,0,1,1,0,1,1,1,1,1,1,0,1,0,0,0,0,1,1,1,0,1,1$

Table 4 - Matching matrix for experimental data array 2

DATA $1,0,0,0,0,0,0,0,0,0,0,0,0,0,1,0,0,0,1,1$

DATA $1,1,0,1,1,1,1,0,0,0,1,1,1,1,1,1,1,1,1,1$

DATA $1,1,1,1,1,1,1,0,0,0,1,1,1,0,1,1,1,0,1,1$

DATA $1,0,0,1,0,1,0,0,0,0,0,0,1,1,1,1,1,0,1,1$

DATA $1,0,0,1,1,0,0,0,0,0,0,0,0,0,1,0,0,0,1,1$

DATA $1,0,0,0,1,1,1,1,0,0,1,1,0,0,0,0,0,0,1,1$

DATA $1,0,0,1,1,0,1,0,0,0,0,1,1,1,1,1,1,1,1,1$

DATA $1,1,1,1,1,0,1,1,0,1,1,1,1,1,1,1,1,1,1,1$

DATA $1,1,1,1,1,1,1,1,1,1,1,1,1,1,1,1,1,1,1,1$

DATA $1,1,1,1,1,1,1,0,0,1,1,1,1,1,1,1,1,1,1,1$

DATA $1,0,0,1,1,0,1,0,0,0,1,0,0,0,0,0,0,0,1,1$

DATA $1,0,0,1,1,0,0,0,0,0,1,1,0,0,0,0,0,0,1,1$

DATA $1,0,0,0,1,1,0,0,0,0,1,1,1,0,1,0,0,0,1,1$

DATA $1,0,1,0,1,1,0,0,0,0,1,1,1,1,1,0,1,1,1,1$

DATA $0,0,0,0,0,1,0,0,0,0,1,1,0,0,1,0,0,0,1,1$

DATA $1,0,0,0,1,1,0,0,0,0,1,1,1,1,1,1,1,1,1,1$

DATA $1,0,0,0,1,1,0,0,0,0,1,1,1,0,1,0,1,0,1,0$

DATA $1,0,1,1,1,1,0,0,0,0,1,1,1,0,1,0,1,1,1,0$

DATA $0,0,0,0,0,0,0,0,0,0,0,0,0,0,0,0,0,0,1,0$

(C) Irodov V. F., Barsuk R. V., 2020

DOI 10.15588/1607-3274-2020-1-20 


\section{RESULTS}

There are presented results with choice function in the form (9).

$$
\begin{aligned}
& \quad \Gamma(x)=d_{1}+d_{2}+d_{3}, \\
& d_{1}=\left(a_{1}+a_{2} x^{1}+a_{3} x^{1} x^{1}\right)\left(a_{4}+a_{5} x^{2}+a_{6} x^{2} x^{2}\right), \\
& d_{2}=\left(a_{7}+a_{8} x^{3}+a_{9} x^{3} x^{3}\right)\left(a_{10}+a_{11} x^{4}+a_{12} x^{4} x^{4}\right), \\
& d_{3}=\left(a_{13}+a_{14} x^{4}+a_{15} x^{4} x^{4}\right)\left(a_{16}+a_{17} x^{5}+a_{18} x^{5} x^{5}\right), \\
& \Gamma\left(x_{1}\right) \geq \Gamma\left(x_{2}\right) \equiv x_{1} R_{S} x_{2} .
\end{aligned}
$$

Parameters $a_{1}, a_{2}, \ldots, a_{18}$ were obtained after evolutionary search the choice function for array 1 of experimental data and for array 2 of experimental data.

The choice function in the form (19) with specific values of parameters $a_{1}, a_{2}, \ldots, a_{18}$ was used to solve the problem of generalized mathematical programming: to find maximum choice function with restrictions: $0.2<=x^{i}=<0.5, i=1, \ldots, 5$. Evolutionary search for solving the problem of generalized mathematical programming is illustrated at tabl. 6 and results of evolutionary search for three branches of evolution are presented in Table 7.

\section{DISCUSSION}

It is advisable to discuss the stated decision-making mechanism. The first stage of the decision-making mechanism is the experimental study of the system. When conducting experiments, it is desirable to examine as widely as possible the allowable input parameters $x=\left\{x_{1}\right.$, $\left.x_{2}, \ldots, x_{n}\right\}$. It does not require the use of experimental planning methods. The tables of experimental results are a typical example. A visual analysis of the experimental results shows the existence of interdependencies of the output parameters (functions) among themselves.

The controversial nature of the mutual influence of output parameters is clearly seen. Matrix of conformity (Table 3 and Table 4) is the result of expert assessment and is subjective. For expert assessment, it is obviously possible to use the whole variety of available pair-wise comparison methods and use a different scale for such an assessment. The choice function given in the article in the form of an algebraic function is certainly not the only possible one, here you can use the whole variety of pattern recognition methods, for example [19, 20].

An important property of such a function is the reliability of the reflection of experimental results not only for the training sequence, but also for the checking sequence of experimental results. The use of an evolutionary search algorithm with several branches of evolution is convenient for controlling the found solution. For example, from Table 6 it can be seen that as a result of the search, the value of the choice function reached a maximum (one) in all three branches of the evolution of solutions. The values of the parameters are basically the same, although there is a slight discrepancy in some parameters.

This suggests that the maximum of this choice function is poorly defined. If in the search process there was no convergence of results across different branches of evolution, this would indicate the absence of a single solution. In this example, the solutions found for the three branches of evolution are almost identical, which indicates the presence of a global maximum of the choice function.

Table 5 - Evolutionary search the choice function

\begin{tabular}{|c|c|c|}
\hline Iteration step of evolutionary search & Error at the training array 1 & Error at the test array 2 \\
\hline 1 & 0.2912 & 0.3975 \\
\hline 2 & 0.2656 & 0.4425 \\
\hline 6 & 0.2464 & 0.2675 \\
\hline 10 & 0.2400 & 0.2675 \\
\hline 14 & 0.2336 & 0.2675 \\
\hline 18 & 0.2240 & 0.2675 \\
\hline 27 & 0.1856 & 0.2675 \\
\hline 38 & 0.1664 & 0.2525 \\
\hline 96 & 0.1536 & 0.2575 \\
\hline 214 & 0.1440 & 0.2575 \\
\hline
\end{tabular}

Table 6 - Evolutionary search for solving the problem of generalized mathematical programming

\begin{tabular}{|c|c|c|c|}
\hline $\begin{array}{c}\text { Iteration step } \\
\text { of evolution }\end{array}$ & $\begin{array}{c}\text { Maximum function } \\
\text { Branch 1 of evolution }\end{array}$ & $\begin{array}{c}\text { Maximum function } \\
\text { Branch 2 of evolution }\end{array}$ & $\begin{array}{c}\text { Maximum function } \\
\text { Branch 3 of evolution }\end{array}$ \\
\hline 1 & $-1.47 \mathrm{E}-7$ & $-1.57 \mathrm{E}-7$ & $-1.30 \mathrm{E}-7$ \\
\hline 2 & $8.45 \mathrm{E}-7$ & $-1.28 \mathrm{E}-7$ & $7.65 \mathrm{E}-7$ \\
\hline 5 & $1.53 \mathrm{E}-6$ & $5.02 \mathrm{E}-6$ & $0.78 \mathrm{E}-5$ \\
\hline 11 & 0.202 & 0.185 & 0.111 \\
\hline 14 & 0.9950 & 0.9993 & 0.9953 \\
\hline 15 & 0.9996 & 1 & 0.9981 \\
\hline 16 & 1 & 1 & 0.9985 \\
\hline 17 & 1 & 1 & 0.9999 \\
\hline 19 & 1 & 1 & 0.9999 \\
\hline
\end{tabular}

Table 7 - Result of evolutionary search for solving the problem of generalized mathematical programming

\begin{tabular}{|c|c|c|c|c|c|}
\hline \multirow{2}{*}{ Branches of evolution } & $\begin{array}{c}\text { Parameter 1 } \\
x^{1}\end{array}$ & $\begin{array}{c}\text { Parameter 2 } \\
x^{2}\end{array}$ & $\begin{array}{c}\text { Parameter 3 } \\
x^{3}\end{array}$ & $\begin{array}{c}\text { Parameter 4 } \\
x^{4}\end{array}$ & $\begin{array}{c}\text { Parameter 5 } \\
x^{5}\end{array}$ \\
\hline Branch 1 & 0.3800 & 0.5 & 0.2 & 0.4511911 & 0.2 \\
\hline Branch 2 & 0.4080 & 0.5 & 0.2 & 0.4511911 & 0.2 \\
\hline Branch 3 & 0.3949 & 0.5 & 0.2 & 0.4511911 & 0.2020 \\
\hline
\end{tabular}

(C) Irodov V. F., Barsuk R. V., 2020

DOI 10.15588/1607-3274-2020-1-20 


\section{CONCLUSIONS}

The constructed selection function is determined already on the whole admissible space of input parameters, and not only on the set of experimental points.

Thus, the selection mechanism extends to the entire allowable range of input parameters.

The scheme includes the following procedures: an experimental study of a process with several criteria (functions) depending on its parameters; the use of expert evaluation to build a matrix of preferences for individual implementations; building a function of choosing preferred solutions based on a preference matrix by constructing a mathematical model of preference recognition, formulation and solving the problem of generalized mathematical programming as the final step in building the selection mechanism.

The scientific novelty is result presented as a holistic decision-making mechanism for a system based on inductive modeling of complex systems, in which the following steps can be distinguished: an experimental study of a process with several criteria (functions) depending on its parameters; the use of expert evaluation to build a matrix of preferences for individual implementations; building a function of choosing preferred solutions based on a preference matrix by constructing a mathematical model of preference recognition, formulation and solving the problem of generalized mathematical programming as the final step in building the selection mechanism.

The practical significance of obtained results is that the stated decision-making mechanism can be used for a wide range of complex systems with several criteria.

Prospects for further research are to the improvement of methods and means for constructing a function of choice for a limited number of experimental results.

\section{ACKNOWLEDGEMENTS}

This work was carried out within the framework of the budget research work of the Pridneprovska State Academy of Civil Engineering and Architecture (state registration number 0112U005350).

\section{REFERENCES}

1. Fishburn P. Representiable choice function, Econometrica, 1976, Vol. 44, No. 5, pp. 1033-1043.

2. Ajzerman M. A., Aleskerov F. T. Vibor variantov: osnovi teorii. Moscow, Nauka, 1990, 240 p. ISBN 5-02-014091-0.

3. Ajzerman M.A. Nekotorie novie zadachi obchej teorii vibora (obzor odnogo napravleniya issledovaniy), Avtomat. telemeh., 1984, No. 9, pp. 5-43.

4. Sholomov L.A. Logicheskie metodi postroeniya i analiza modeley vibora. Moscow, Nauka, 1989, 288 p. ISBN 5-02014108-9.

5. Ivakhnenko A.G. Heuristic Self-Organization in Problems of Engineering Cybernetics, Automatica, 1970, Vol. 6, pp. 207-219.

6. Ivakhnenko A.G. Polynomial Theory of Complex Systems, IEEE Transactions on Systems Man and Cybernetics, 1971, Vol. 4, pp. 364-378.
7. Lemarchand L., Masse D., Rebreyend P., Hakansson J. Multiobjective optimization for multimode transportation problems, Advances in Operations Research, 2018, Vol. 2018, 13 p. https:// doi.org/10.1155/2018/8720643.

8. Sagawa M., Kusuno N., Aguirre H., Tanaka K., Koishi M. Evolutionary multiobjective optimization including practically desirable solutions, Advances in Operations Research, Article ID 9094514, 2017, Vol. 2017, 16 p. https:// doi.org/10.1155/2017/9094514.

9. Giagkiozis I., Fleming P. J. Pareto front estimation for decision making, Evolutionary computation, 2014, Vol. 22, No. 4, pp. 651-678. //www.researchgate/publication/261369702.

10. Wang Y., Sun X. A many-objective optimization algorithm based on weight vector adjustment, Computational Intelligence and Neuroscience, 2018, Vol. 2018, Article ID 4527968, 21 p. DOI: 10.1155/2018/4527968

11. Yudin D. B. Generalized mathematical programming, Economics and Mathematical Methods, 1984, Vol. 20, pp. 148167.

12. Judin D.B. Vichislitelnie metodi teorii prinyatiya resheniy / D.B. Judin. - M. : Nauka, 1989. - 320 p.

13. Kolbin V. V. Generalized mathematical programming as a decision model, Applied Mathematical Sciencies, 2014, Vol. 8, No. 70, pp. 3469-3476. DOI 10.12988/ams.2014.44231.

14. Irodov V. F., Maksimenkov V. P. Application of an evolutionary program for solving the travelling-salesman problem, Sov. Autom. Control ; translation from Avtomatika, 1981, No. 4, pp. 7-10. io-port.net Database 03803175.

15. Irodov V.F. The construction and convergence of evolutional algorithms of random search for self-organization, Sov. J. Autom. Inf. Sci. 20 ; translation from Avtomatika, 1987, No.4, pp. 34-43. io-port.net Database 04072731.

16. Irodov V.F. Self-organization methods for analysis of nonlinear systems with binary choice relations, System Analysis Modeling Simulation, 1995, Vol. 18-19, pp. 203206. https://dl.acm.org/citation.cfm?id=208028\#.

17. Irodov V. F., Khatskevych Yu. V. Convergence of evolutionary algorithms for optimal solution with binary choice relations, Stroitelstvo, materialovedenie, mashinostroenie : Sb. nauch. trudov. Dnepr, 2017, Vol. 98, pp. 91-96. http://nbuv.gov.ua/UJRN/smmeect_2017_98_16.

18. Barsuk R. V., Irodov V. F. Matematichne modeliuvannya funkcii viboru perevazhnih rishen dlya trubchastih gazovih nagrivachiv za eksperimentalnoiy informazieiy, Visnik Pridneprovskoi derzhavnoi akademii budivniztva ta architecturi : zb. nauk. prats. Dnipro, 2016, No. 8(221), pp. 17-25. http://oaji.net/articles/2017/2528-1507122475.

19. Subbotin S. A. The neuro-fuzzy network synthesis and simplification on precedents in problems of diagnosis and pattern recognition, Optical Memory and Neural Networks (Information Optics), 2013, Vol. 22, No. 2, pp. 97-103. DOI: $10.3103 / \mathrm{s} 1060992 \times 13020082$.

20. Subbotin S. A. Methods of sampling based on exhaustive and evolutionary search, Automatic Control and Computer Sciences, 2013, Vol. 47, No. 3, pp. 113-121. DOI: $10.3103 / \mathrm{s} 0146411613030073$ 


\section{ПРИЙНЯТТЯ РІШЕНЬ ПРИ НАЯВНОСТІ ОБМЕЖЕНОГО ЧИСЛА ЕКСПЕРИМЕНТІВ 3 ДЕКІЛЬКОМА КРИТЕРІЯМИ}

Іродов В. Ф. - д-р техн. наук, професор, завідувач кафедри системного аналізу та моделювання у теплогазопостачанні Придніпровської державної академії будівництва та архітектури, Дніпро, Україна.

Барсук Р. В. - асистент кафедри системного аналізу та моделювання у теплогазопостачанні Придніпровської державної академії будівництва та архітектури, Дніпро, Україна.

АНОТАЦІЯ

Актуальність. Розглянуто задачу прийняття рішень для системи з декількома критеріями на основі обмеженої кількості експериментальних результатів. Об'єктом дослідження є процес прийняття рішень, починаючи з експериментального дослідження системи до рішення задачі оптимізації системи з декількома критеріями.

Мета. Мета роботи - викладення цільного механізму прийняття рішень для системи з декількома критеріями на основі обмеженої кількості експериментів.

Метод. Запропоновано використовувати алгоритми еволюційного пошуку переважних рішень для двох основних процедур: пошук оптимальної функції вибору на базі матриці пере важності експериментальних рішень; пошук оптимальних по бінарному відношенню вибору рішень на всій множині допустимих параметрів (рішення задачі узагальненого математичного програмування). Алгоритм еволюційного пошуку, який застосовується, вирішує задачу пошуку оптимальних по бінарному відношенню вибору рішень без потреби випуклості відношення вибору. У роботі застосовані експериментальні результати дослідження пальника на паливних гранулах (пелетах). Вхідні параметри системи налічують п'ять розмірних параметрів, а вихідні параметри три розмірні критерії. Усього експерименти налічують 45 результатів, 3 яких 25 експериментів склали навчальну послідовність і 20 результатів - контрольну послідовність, які застосовувались для отримання функції вибору.

Результати. Розроблена цільна система побудови механізму прийняття рішень для системи з декількома критеріями на основі обмеженої кількості експериментів.

Висновки. Наведені експерименти та їх обробка показали достовірність основних наукових результатів - можливості побудови механізму вибору у системі з декількома критеріями на основі обмеженої кількості експериментів і поширення кінцевого вибору на всю допустиму область вхідних параметрів, а не тільки на множині експериментальних результатів.

КЛЮЧОВІ СЛОВА: механізм прийняття рішень, декілька критеріїв, функція вибору, узагальнено математичне програмування.

\section{УДК 519.816 \\ ПРИНЯТИЕ РЕШЕНИЙ ПРИ НАЛИЧИИ ОГРАНИЧЕННОГО КОЛИЧЕСТВА ЭКСПЕРИМЕНТОВ С НЕСКОЛЬКИМИ КРИТЕРИЯМИ}

Иродов В. Ф. - д-р техн. наук, профессор, заведующий кафедрой системного анализа и моделирования в теплогазоснабжении Приднепровской государственной академии строительства и архитектуры, Днепр, Украина.

Барсук Р. В. - ассистент кафедры системного анализа и моделирования в теплогазоснабжении Приднепровской государственной академии строительства и архитектуры, Днепр, Украина.

\section{АННОТАЦИЯ}

Актуальность. Рассмотрена задача принятия решений для системы с несколькими критериям на основе ограниченного количества экспериментальных результатов. Объектом исследования является процесс принятия решений, начиная с экспериментального исследования системы к решению задачи оптимизации системы с несколькими критериями.

Цель. Цель работы - изложение цельного механизма принятия решений для системы с несколькими критериям на основе ограниченного количества экспериментов

Метод. Предложено использовать алгоритмы эволюционного поиска предпочтительных решений для двух основных процедур: поиск оптимальной функции выбора на базе матрицы предпочтительности экспериментальных решений; поиск оптимальных по бинарному отношению выбора решений на всем множестве допустимых параметров (решение задачи обобщенного математического программирования). Алгоритм эволюционного поиска, который применяется, решает задачу поиска оптимальных по бинарному отношению выбора решений без требования выпуклости отношение выбора. В работе применены экспериментальные результаты исследования горелки на топливных гранулах (пеллетах). Входные параметры системы насчитывают пять размерных параметров, а выходные параметры три размерные критерии. Всего эксперименты насчитывают 45 результатов, из которых 25 экспериментов составили учебную последовательность и 20 результатов - контрольную последовательность, которые применялись для получения функции выбора.

Результаты. Разработана цельная система построения механизма принятия решений для системы с несколькими критериям на основе ограниченного количества экспериментов.

Выводы. Приведенные эксперименты и их обработка показали достоверность основных научных результатов - возможности построения механизма выбора в системе с несколькими критериям на основе ограниченного количества экспериментов и распространения конечного выбора на всю допустимую область входных параметров, а не только на множестве экспериментальных результатов.

КЛЮЧЕВЫЕ СЛОВА: механизм принятия решений, несколько критериев, функция выбора, обобщенное математическое программирование. 


\section{ЛІТЕРАТУРА / ЛИТЕРАТУРА}

1. Fishburn P. Representiable choice function / P. Fishburn // Econometrica. - 1976. - Vol. 44, № 5. - P. 1033-1043.

2. Айзерман М.А. Выбор вариантов : основы теории / М. А. Айзерман, Ф.Т. Алескеров. - М. : Наука, Гл. ред. физ.-мат. лит., 1990. - 240 с. - ISBN 5-02-014091-0.

3. Айзерман M.A. Некоторые новые задачи общей теории выбора (обзор одного направления исследований) / М. А. Айзерман // Автомат. и телемех. - 1984. - № 9. C. 5-43.

4. Шоломов Л. А. Логические методы построения и анализа моделей выбора / Л. А. Шоломов. - М. : Наука, 1989. - 288 c.- ISBN 5-02-014108-9.

5. Ivakhnenko A.G. Heuristic Self-Organization in Problems of Engineering Cybernetics / A.G. Ivakhnenko // Automatica. 1970. - Vol. 6. -P. 207-219.

6. Ivakhnenko A.G. Polynomial Theory of Complex Systems / A.G. Ivakhnenko // IEEE Transactions on Systems Man and Cybernetics. - 1971. - Vol. 4. - P. 364-378.

7. Lemarchand L. Multiobjective optimization for multimode transportation problems / L. Lemarchand, D. Masse, P. Rebreyend, J. Hakansson // Advances in Operations Research. - 2018. - Vol. 2018. - 13 p. https:// doi.org/10.1155/2018/8720643.

8. Sagawa M. Evolutionary multiobjective optimization including practically desirable solutions / M. Sagawa, N. Kusuno, H. Aguirre, K. Tanaka, M. Koishi // Advances in Operations Research, Article ID 9094514. - 2017. - Vol. 2017, 16 p. https:// doi.org/10.1155/2017/9094514.

9. Giagkiozis I. Pareto front estimation for decision making / I. Giagkiozis, P. J. Fleming // Evolutionary computation. 2014. - Vol. 22, № 4. - P. 651-678. htts: //www.researchgate/publication/261369702.

10. Wang Y. A many-objective optimization algorithm based on weight vector adjustment / Y. Wang, X. Sun // Computational Intelligence and Neuroscience. - 2018. - Vol. 2018 , Article ID 4527968, 21 p. DOI: 10.1155/2018/4527968.

11. Yudin D.B. Generalized mathematical programming / D. B. Yudin // Economics and Mathematical Methods. 1984. - Vol. 20. - P. 148-167.

12. Юдин Д. Б. Вычислительные методы теории принятия решений / Д. Б. Юдин. - М. : Наука, 1989. - 320 с.
13. Kolbin V. V. Generalized mathematical programming as a decision model / V. V. Kolbin // Applied Mathematical Sciencies. - 2014. - Vol. 8, № 70. - P. 3469-3476. DOI 10.12988/ams.2014.44231.

14. Irodov V. F. Application of an evolutionary program for solving the travelling-salesman problem / V.F. Irodov, V. P. Maksimenkov // Sov. Autom. Control ; translation from Avtomatika. - 1981. - № 4. - P. 7-10. io-port.net Database 03803175 .

15. Irodov V. F. The construction and convergence of evolutional algorithms of random search for self-organization / V.F. Irodov // Sov. J. Autom. Inf. Sci. 20 ; translation from Avtomatika. - 1987. - № 4. - P. 34-43. io-port.net Database 04072731

16. Irodov V. F. Self-organization methods for analysis of nonlinear systems with binary choice relations / V. F. Irodov // System Analysis Modeling Simulation. - 1995. - Vol. 1819. - $\quad$ P. 203-206 https://dl.acm.org/citation.cfm?id=208028\#.

17. Irodov V.F. Convergence of evolutionary algorithms for optimal solution with binary choice relations / V. F. Irodov, $\mathrm{Yu}$. V. Khatskevych // Строительство. Материаловедение. Машиностроение : сб. науч. тр. / Приднепров. гос. акад. стр-ва и архитектуры. - Дн-вск, 2017. - Вып. 98. - С. 9196. - (Серия: Энергетика, экология, компьтерные технологии в строительстве). http://nbuv.gov.ua/UJRN/smmeect_2017_98_16.

18. Барсук Р. В. Математичне моделювання функції выбору переважних рішень для трубчастих газових нагрівачів за експериментальної інформації / Р. В. Барсук, В. Ф. Іродов // Вісник Придніпровської державної академії будівництва та архітектури : зб. наук. пр. / Придніпров. держ. акад. буд-ва та архітектури. Дніпропетровськ, 2016. - №8(221). - C. 17-25. http://oaji.net/articles/2017/2528-1507122475.

19. Subbotin S. A. The neuro-fuzzy network synthesis and simplification on precedents in problems of diagnosis and pattern recognition / S. A. Subbotin // Optical Memory and Neural Networks (Information Optics). - 2013. - Vol. 22, № 2. - P. 97-103. DOI: 10.3103/s1060992x13020082.

20. Subbotin S. A. Methods of sampling based on exhaustive and evolutionary search / S. A. Subbotin // Automatic Control and Computer Sciences. - 2013. - Vol. 47, № 3. P. 113-121. DOI: 10.3103/s0146411613030073. 